\title{
A POLITIKA MINT ÉRTELMEZETT CSELEKVÉS
}

\author{
Gyáni Gábor
}

A recenzió beérkezett: 2020. április 13., véglegesítve: 2020. április 13.

Szabó Márton politikatudományi életmúvének a summázatát nyújtja újabb politikai episztemológiai munkájában. A szerző célkitűzése egy új, kellően még nem meghonosodott, diszkurzívnak, interpretatívnak, vagy konstruktivistának nevezett politikatudományi szemléletmód elvi alapjainak a kidolgozása és vitára bocsátása, amely a nyelvi fordulat nyomán kibontakozó humán- és társadalomtudományi diskurzusok sorába illeszkedik. A politika világát a szerző nem pozitív tényszerűségében, nem valamiféle adottságként, hanem a politikai cselekvés során, az annak eredményeként előálló viselkedésformák, intézmények és szervezetek világaként mutatja be. A cselekvés, mint szöveg olvasható, és ekképp az értelmezéssel kapcsolódik szorosan össze. Ez így a politika hermeneutikai fogalmi keretbe helyezett szemléletét ígéri Szabó, ugyanakkor fenomenológiai alapra is helyezkedik, hogy a nyilvános és kommunikált politikai cselekvés közegében pillantson a politikumra. Következésképpen a politika fogalma számára nem szubsztantív lényeggel bíró objektivitás, hanem az a szubjektivitás, amely társas kapcsolati formában, egyúttal nyilvánosan hat és létezik. Döntő elem ebben az értelmezés folytonossága, ami nélkül nincs, nem lehet objektiválás, és par ecxellence politikai létezés. A könyv Keretek címú fő fejezetében, ahol az értelemtulajdonító politikai cselekvés intézményesüléséről, szervezetek keretei közötti múködéséről esik szó, Szabó azt állítja, hogy a politika "tényszerüsége" a szervezet diszkurzivitásával egyenértékű dologiság. A szervezetek szabályalkotó, szabálykövető, és a szabályokat betartató társadalmi formák is egyúttal. A szervezetek tagjai azon túl, hogy követik, egyúttal értelmezik is a szabályt, következésképpen ók maguk alkotják meg a szervezetek szabályait; másként kifejezve, a szervezeti kereteken belüli cselekedeteikkel ők tartják fenn a szervezeti múködést. Mindezek mélyén pedig a saját, másokkal egyeztetett értelmezések, jelentéstulajdonítások bújnak meg. Az egyéni cselekvés azáltal ölt politikai jelleget, hogy szükségképpen túllép a privát élet körén, általánosodik, egyszóval társas jellegưvé válik.

A diszkurzív politikatudomány szemléleti kiindulópontja a tény pozitivista fogalmának elvetése és helyettesítése azzal, amit a diszkurzív politikai cselekvés elgondolása követel. A politikai tény úgy és azáltal létezik, hogy a politikai cselekvő́k politikai jelentéssel ruháznak fel valamit, aminek egyszer- 
smind politikai jelentőséget is kölcsönöznek. A politika ezáltal nem objektív adottság, hanem keletkeztetett létező. A keletkeztetés eszköze és sajátos közege a nyelv, a nyelviség, tehát a beszéd és az írott szöveg, melynek központi szerepe van a politikai valóság konstituálásában. A nyelv nem járulékos és nem is csak díszítő elem, hanem a politikai akaratot, a politikai képzetet artikuláló, azt objektiváló tényező. Amikor a diszkurzív politikatudomány múvelője célul tûzi maga elé a politikai cselekvés megfigyelését és értelmezését, akkor ezeknek a szövegeknek a beható tanulmányozásába vág a megértésük érdekében. Nem csak a hallott és olvasott szövegek hordoznak magukban sajátlagosan politikai jelentést, de még a holt tárgyak is közölhetnek velünk ilyen tudattartalmakat, jóllehet nem épp ezért hozták létre őket annak idején.

A szövegszerű emberi tettek tanulmányozása konkrét nézőponthoz kötött vizsgálódást jelent, amely a politikai eseményeket önnön tapasztalati valóságukban, és nem a szükségszerûségek megnyilatkozásaiként fogja fel; ebből fakad, hogy még a lehetőségek sem sikkadnak el a számbavétel során. A kutató ennek során a politikai tények fikcionalitására is figyel, mert tudja, hogy közvetett módon férhet csupán hozzá a politikai tényekhez. A diszkurzív politikatudomány nem tagadja ugyan a politika törvényelvú megnyilvánulását és ekként való magyarázhatóságát, ami magyarázatot követel, mégis inkább a megértésre helyezi a hangsúlyt. Szabó Paul Ricoeurt, a hozzá igen közelálló teoretikust követi, amikor megállapítja: a megértett, a saját motívumai felől rekonstruált cselekvő nem hagyja ugyanakkor kiaknázatlanul az oksági sorok nyújtotta cselekvési lehetôségeket sem. Ezért az utóbbiak számbavétele sem mellőzhető teljes mértékben a politikatudományi elemzésben.

Az ágensek részéről szüntelenül értelmezett politikai létező, amely cselekvés formájában aktualizálódik (és ebbe valamely szöveg előállítása is beleértendő), a beszédaktus-elmélet szószólói (John L. Austin, John R. Searle) szerint maga is tettnek számít. Az így tekintett cselekvés - mint konkrét általános a tipikusban, de nem az átlagosban - mutatkozik meg a szemlélő számára. A szervezetszociológiai megközelítés tanulságai szerint a politika olyan egyedi és lokális magatartás, melyre az intézményesedés, valamint a szervezeti keretek között érvényesülő szabályok, hagyományok és normák hatnak alakító módon. A diszkurzív alapokra helyezett politikatudomány azonban, ahogy azt korábban már említettük, nem úgy tekint ezekre a szabályokra és normákra mint eleve adott entitásokra, hanem akként fogja fel őket, mint amelyek csupán lettek: hiszen létüket az őket értelmező gyakorlatoknak köszönhetik. Ezért nem azt vizsgáljuk itt, hogy mi a norma és a szabály, hanem azt a "tényt" igyekszünk kideríteni, hogy a politika ágensei, a cselekvő emberek miként értik, és miként alkalmazzák az általuk normaként értett szabályt. A politikatudomány úgy és akkor kerül közel az empirikus vizsgálat során a politizálás tényleges világához, amikor a politikai nyelvet, közvetve az állampolgárok politikaértelmezését firtatja, amely feltárja előtte a cselekvések logikáját. 
Szabó Márton episztemológiai szintézise monumentális szellemi alkotás: amellett, hogy kellőképpen átgondolt, az egyes részleteit tekintve is gondosan kidolgozott építmény. Olyan új paradigmatikus megközelítés kiáltványa ez a munka, amely lefekteti az empirikus politikatudomány számára javasolt új irány elvi, fogalmi fogódzóit.

Ha kritikával illethetjük ezt a munkát, akkor abból indulhatunk ki, hogy Szabó számos tekintetben a formális szociológiai megközelítés módszertanát követi, és ez olykor problémákat is felvet. A politikai értelemben cselekvő egyes ember, aki a valóságot értelmezve a társas élet alakítójává válik, csupán a maga elvontságában jelenik meg előttünk. Ennek kapcsán pedig felvethető a kérdés: ez az ágens nem rendelkezik vajon szociológiailag meghatározható minőséggel is, amely árnyalja, valamelyest talán még meg is szabja a politikai viselkedését? Hadd érzékeltessem mindezt egyetlen példával. Szabó sugalmazása szerint mindenki számára egyaránt adva van az a lehetôség, hogy - másokkal karöltve - politikai cselekvésbe fordítsa át ennek az értelmezett valóságnak a teremtését, formálását és a megváltoztatását. Valóban így lenne?

A társadalom szociológiai tagoltsága, beleértve a jogok és a materiális, valamint a szimbolikus tőke rendszerint egyenlőtlen eloszlását, legalábbis megkérdőjelezi ezt a feltételezést. Úgy vélem kizárt dolog ennek a posztulált egyöntetûségnek és egyenlőségnek a puszta lehetősége is. A cselekvőség, az ágencia fogalma mindig konkrét feltételekhez kötött emberi képességet jelöl, s ez nem feltétlenül (csak) antropológiai, hanem kifejezetten történeti „adottság"-ot jelent. A történelmi cselekvőség elméleti irodalmában soha sem beszélnek elvont módon arról a kérdésről, hogy a történelmi ágens képes-e vajon az erőforrásokat úgy ellenőrizni, hogy változtathasson a struktúrán. Ez a képesség ugyanis nem mindenki számára adott egyforma mértékben. Minden emberben megvan ugyan a képesség a cselekvésre, amely éppolyan adottságunk, mint a nyelvhasználat képessége, amely egy meghatározott, nevezetesen az anyanyelv elsajátításának a képessége az emberi faj minden egyes tagja esetében. Viszont a cselekvőség konkrét formája módfelett változatos lehet koronként és kultúránként és még ugyanazon a közösségen belül is sokféleképpen nyilvánulhat meg. Azért is, mert a cselekvés képessége (az azt előkészítő interpretációval együtt) kulturálisan és történelmileg egyaránt determinált létező. Az a "tudás”, amit a cselekvőség feltételez és megkíván, jellemzően egyenlőtlen módon oszlik el a közösség tagjai között; a többség többnyire csak elszenvedi, rutin jellegú ténykedésével éppenséggel fenn is tartja (és nem feltétlenül reflektálja) a struktúrát, ahelyett, hogy módosítana rajta. Ha a helyzet nem ez lenne, akkor olyan fokú dinamizmus hatná át az emberi világot, hogy lehetetlen lenne élni benne. ${ }^{1}$

A diszkurzivitás mindent átható mibenlétét tételezve Szabó nem tisztázza kellőképpen a törvényelvű oksági összefüggések helyét és szerepét a politika világában, és ezzel némileg homályban hagyja a diszkurzív és a tisztán dolo- 
gi tényezők egymáshoz mért súlyát és jelentőségét a politika konstituálásában és múködtetésében. Könyve egy helyén ismerteti ugyan Ricoeur egyik tanulmányát, és el is fogadja a benne foglaltakat, mely szerint ez a kettő kiegészíti egymást. Máshol viszont, ott például ahol az interpretatív szervezetelmélet téziseit fejtegeti, inkább arra hajlik, hogy az oksági determinációnak nincs igazán helye ebben a világban. A szervezet ott részletezett és öt pontban összegzett tulajdonságai között nem utal ugyanis az oksági sorok szerepére a szervezeti múködés feltételeit tekintve. Ráadásul meg is bírálja annak a koncepciónak a híveit, akik túl engedékenyek szerinte a nem tisztán fenomenológiai érvelés tekintetében. „Ezen a ponton vitatnám az interpretatív szervezetelméletek azon törekvését, hogy itt fel kellene tárni valami mélyen rejtőző értelmezési struktúrát vagy az értelmezések mögöttes jelentéseit. Ugyanis a 'mélyebb jelentés' is jelentés, amely csak akkor létezik, ha valaki megfogalmazta, amely mögött persze újabb jelentéseket lehet találni, ad infinitum...".2

Mi itt a probléma? Fő́ként az, hogy a jelentésnek, mint a valóság teremtésének ezzel a kiemelt kezelésével látszólag eltûnik a struktúra, a rögzült jelentés valóságformáló hatásának szerepe az élet formálásából. Ha kiiktatjuk a strukturális determinációt az oksági összefüggések sorából, akkor könnyen elvesztheti a talajt a racionális gondolkodás, miután nincs többé mit magyaráznia. Úgy gondolom azonban, hogy a magyarázat (az okság) és a megértés (az ágensi diszkurzivitás) elméleti összehangolása továbbra is elengedhetetlen a diszkurzív politikatudomány számára is. Ha így van, akkor megkerülhetetlen, hogy kidolgozzuk a kauzalitásnak azt az elméletét, amelyet összhangba hozhatunk a diszkurzivitás itt kifejtett koncepciójával. Szabó a könyvében sokkal inkább lemondani látszik az oksági magyarázatról, mint hogy megkísérelné egy ilyen interaktív kapcsolat bizonyítását.

A formális politikai szociológiai megközelítésnek szükséges velejárója a konkrét meghatározottság fogalmi mellőzése; e megközelítés során így többnyire elvész az időbeliség (a történetiség), valamint a sokféle létező egyidejüségének (a különböző idejüségek egyidejûségének) a figyelembe vétele. Erre az eljárásra (és deficitre) jó példa Simmel szociológiája, ahol empirikus szinten a történeti példálózás helyett antropológiai utalások hivatottak hitelesíteni az elméleti mondandót. ${ }^{3}$ A politika fogalmának ezt a fajta homogenizálását, egyetlen ideáltipikus és persze időtlen politikai megnyilvánulásra történő leszúkítését a politika diszkurzív koncepciójának a megfogalmazása kívánja meg. A veszteség azonban nyilvánvaló ennek során, különösen, ami a gyakorlati alkalmazhatóságot illeti, amire pedig Szabó nagy hangsúlyt fektet. Erősen kísért ugyanis a veszély, hogy könnyen összemosódnak egymással a jellegükben eltérő politikumok. Ami például a modern kort illeti, a diszkurzivitás úgymond egyetemes fogalma differenciálatlanul kezeli a nyugati típusú demokráciákat és a kelet-európai típusú diktatúrákat. Történészként is aggályosnak tartom ezt a gyakorlatot, mert egészen nyilvánvaló, hogy a diszkurzív politika Szabó 
által képviselt fogalma jószerivel csak a fejlett demokráciák politikai tapasztalatainak felel meg. Ha azonban az általa javasolt fogalmi konstrukció egyetemes érvényre tart számot, akkor ez legalábbis megalapozatlan igénynek tưnik. ${ }^{4}$

Szabó munkája olyan politikaelméleti fejtegetés, amely a metatudomány nyelvén szólal meg. A szerző nem egy összefüggő elméleti konstrukciót alkot, hébe-hóba támaszkodva eközben mások gondolataira, hanem a témát illető elméleti diskurzus anyagának extenzív, ugyanakkor beható, nemegyszer részletező bemutatásával körvonalazza a saját elképzeléseit. Ez a megoldás két problémát is felvet. Az egyik, hogy mivel a politikatudomány körében egy még nem teljesen kifejlett elméleti konstrukcióval van dolgunk, Szabónak olykor más tudományok elméleti diskurzusaihoz kell fordulnia segítség gyanánt; kivált fontosak számára a történetelméleti argumentumok, és persze az elméleti szociológia szintúgy. Nem mindig lehet azonban biztos benne, hogy amit átemel belőlük az adaptáció jegyében, az a politikatudomány nézőpontjából is valóban releváns. Olykor az az érzésem támadt, hogy elmaradt a kívánatos szelekció és a gondos mérlegelés e tekintetben, és így olyan gondolati elemek is felbukkannak immár a politikatudomány kontextusában, melyeknek ott igazán nincs is helyük.

Erre nézve jellemző eset a szervezet témájának szentelt fejezet, sőt ezeknek a fejezeteknek az egymást követő sora, amely tele van olyan általános szervezetelméleti fejtegetésekkel, amelyek nem feltétlenül vonatkoznak arra, ami a politikai szervezetek sajátosságát képezi. Ezt a visszásságot talán a szerző maga is érezhette, mert egy helyt megjegyzi: „Külön politikai szervezetelmélet egyáltalán nem is létezik. ${ }^{\prime \prime}$ Hozzáértés hiányában sem megerősíteni, sem megcáfolni nem tudom a kijelentést, bár bizonyos kétkedéssel fogadom az idézett megállapítást. Ugyanakkor Szabó sem terjeszti ki a diszkurzivitás fogalmának a hatókörét a politikai szervezetek teljes körére. Ez szerintem helyes döntés volt a részéről. Viszont, ő maga korlátozza ezáltal a diszkurzivitásnak, mint a politikum egyetemleges tulajdonságának a konkrét érvényesülését. Ami némileg ellentmond a diszkurzív politikafogalom számára igényelt univerzalitásnak.

Egy további probléma, hogy a metatudományi nyelvezet, a vele egybecsengő előadásmód nemegyszer bizonytalanságban tartja az olvasót azt illetően, hogy az, amit olvas, a diskurzust ismertető beszámoló vajon, vagy olyasvalami, ami a szerző saját gondolatainak felel meg. A ki beszél itt valójában? kérdése ez, amely egy olyan elbeszélői stratégia miatt okoz problémát a befogadás során, amely tudatosan keveri az alanyi teoretizálást és a metatudományi beszédmódot.

S végül: Szabó nagy elánnal merít a történetelméleti diskurzusból, noha csak szelektíven hasznosítja azt. Ehhez kapcsolódva tenném szóvá az egyik feltûnő hiányérzetemet. Az életvilág és az intézményesedés kapcsán, de máshol is, olyan társadalmasodási, általa általánosodásként megnevezett folya- 
matokat és működési módokat ír le, melyek példaszerű konceptualizálását Hajnal István hajtotta végre még az 1930-as években a történelem és a szociológia elvi összeházasítását ecsetelő híres tanulmányában. ${ }^{6}$ Hajnal arra építette saját, állítólag a német szociológia ellenében kidolgozott objektivációs elméletét, hogy a struktúrát nem mint valamilyen, az élet felett lebegő absztrakt „kultúrkincset" fogta fel. Helyette úgy definiálta a struktúrát (a formaképződést, ahogy ő nevezte), mint ami a személyes érintkezés révén, egymás érzéseinek, gondolatainak a kicserélésével, a cselekvések egybeigazításával képződik társadalmi forma gyanánt; ez időlegesen eltávolodik ugyan az élet folyásától, de szüntelenül vissza is tér oda, hogy a személyies életviszonyokba beleágyazódva lehetővé tegye az élet rendezettségét, miután formát ad neki. Ez az elgondolás egyáltalán nem áll távol attól, amit Szabó az objektiváció fogalmáról ebben a munkájában kifejt; ezért is érdemes lett volna számolnia Hajnal itt érintett elképzelésével. S számos további olyan kurrens történetelméleti argumentációt is megemlíthetnék még, amely jótékonyan segíthette volna a szerzôt elméleti tájékozódásában, így például a postsocial history néven ismert elképzelést és más egyebeket. ${ }^{7}$

Szabó munkája fontos hozzájárulás egy olyan, a politikatudományon meszsze túlmutató humán- és társadalomtudományi elméletalkotási folyamathoz, amely kész szakítani a ténypozitivizmus szemléletmódjával. S Szabó az első lépések egyikét tette meg e tekintetben ezen a szúkebb tudományos területen.

\section{JEGYZETEK}

${ }^{1}$ William H. Sewell, Jr. (2005): Logics of History. Social Theory and Social Transformation. Chicago, University of Chicago Press. Különösen a 124-151. oldalak.

2 Szabó Márton (2016): Diszkurzív politikatudomány. Bevezetés a politika interpretatív szemléletébe és kutatásába. Budapest, Osiris. 245.

${ }^{3}$ Lásd például: Georg Simmel (2009): A társadalmi differenciálódásról. Szociológiai és pszichológiai vizsgálódások. Ford. Weiss János. Budapest, Gondolat.

A Szabó által képviselt diszkurzív politikafogalom ily értelmú kritikáját korábban már megfogalmaztam. Gyáni Gábor: Mitől és mennyire tényszerú a politika? In: Horváth Szilvia-Gyulai Attila (szerk.) (2019): Dialógus, vita, diskurzus. Tanulmányok Szabó Márton diszkurzív politikatudományáról. Budapest, Társadalomtudományi Kutatóközpont-Politikatudományi IntézetL’Harmattan. 32-34.

${ }^{4}$ Szabó Márton: i. m. 257.

${ }^{5}$ Hajnal István (1939): Történelem és szociológia, Századok, 1. szám, 1-32; 2. szám, 137-166. Újraközölve in: Hajnal István (1993): Technika, múvelődés. Tanulmányok. Vál., s.a.r., bev., jegyz. Glatz Ferenc. História-MTA TTI. 157-204.

${ }^{6}$ Miguel A. Cabrera (2004): Postsocial History. An Introduction. Ford. Marie McMahen. Lexington Books, Lanham, 2004. 